Asymmetric enhancement of cAMP in human placental tissues after treatment with bPTH(1-34), J. M. A Williams, K. R. Page, D. R. Abramovich, C. G. Dacke \& T. M. Mayhew

Interactions between feed protein, carbohydrate and fat on the lactational performance of rats. N. C. Friggens, D. E. F. Hay \& J. D. Oldham

Critical nutrient proportions for lactational success in rats. N. C. Friggens, D. E. F. Hay \& J. D. Oldham

Effects of long-term feeding of high-fat diets containing triolein or medium-chain triacylglycerols to lactating rats on the disposal of a meal containing the ${ }^{14} \mathrm{C}$-labelled lipid. Paulo F. A. Souza \& Dermot H. Williamson

How is the energy budget balanced in well-nourished lactating women? $G$. R. Goldberg, H. L. Davies, A. M Prentice, W. A. Coward, M. Sawyer, J. Ashford, P. R. Murgatroyd \& A. E. Black

Effect of a milk-free diet on fetal cord blood milk antibody levels: a study of normal and atopic mothers. J. A Lovegrove, S. M. Hampton, Jane Morgan \& V. Marks

Serum and cord blood levels of anti-ovalbumin and anti-gliadin $\operatorname{lgG}$ in atopic and non-atopic pregnant women. $R$. Morris, S. Hampton, Jane Morgan \& V. Marks

Seasonality in children's growth rates in Southern Ethiopia. F. Branca. G. Pastore, T. Demissie \& A. Ferro-Luzzi

Growth of stunted children given nutritional supplementation and psychosocial stimulation. S. P. Walker. S.M. Grantham-McGregor, C. A. Powell, D. T. Simeon \& J. H. Himes

The effects of nutritional supplementation on the development of stunted children. S. M. Grantham-McGregor. C. A. Powell, S. P. Walker, P. Fletcher \& I. H. Himes

Total energy expenditure during childhood and adolescence. P. S. W. Davies, M. B. E. Livingstone, A. M Prentice, W. A. Coward, S. E. Jagger, C. Stewart, J. J. Strain \& R. G. Whitehead

Comparison of simultaneous measures of energy intake and expenditure in children and adolescents. M. B. E . Livingstone, P. S. W. Davies, A. M. Prentice, W. A. Coward, A. E. Black, J. J. Strain \& P. G. McKenna

Distribution of energy intake in relation to calculated basal metabolic rate and adiposity in a national cohort study. Fiona B. Key, Alison A. Paul, T. J. Cole \& M. E. J. Wadsworth

24 h Energy expenditure and basal metabolic rate in female twins. G. McNeill, J. Love, J. S. Smith \& D. C Morrison

Does genetic variation influence energy expenditure in cystic fibrosis? A. O'Rawe, J. A. Dodge, A. O. Redmond, I. Mclmosh \& D. J. H. Brock

Increased thermic effect of a standard meal in chronically energy-deficient human subjects. L. S. Piers, M. J. Soares \& P. S. Shetty

Family food availability and anthropometric status in Gilan. Iran. F. Rabiee \& C. Geissler

Diet quality. environment and nutritional status in Gilan. Iran. F. Rabiee \& C. Geissler

Knowledge. diet, and stock decisions of small independent retailers with regard to 'healthy' foods. B. J. Tighe, A Wise \& $P$. Cooper

Individuality of portion weights of fat spreads. Catherine H. Kellet \& A. Wise

How much does the public know about fat intake and heart disease? Janet Cade \& Janice Tate

General practitioners' knowledge, attitudes and practices regarding overweight and obesity. Janet Cade \& Shaun $O^{\prime}$ Connell

The effect of energy supplementation on noradrenaline-induced thermogenesis, thermic effect of a meal and basal metabolic rate in chronically energy-deficient human subjects. M. Vaz, R. N. Kulkarni, L. S. Piers, M. J. Soares, A. V. Kurpad \& P. S. Shetty

Acrobic capacity and post-exercise recovery characteristics of chronically energy-deficient labourers. $R . N$. Kulkarni. A. V. Kurpad \& P. S. Shetty

Potentiation as a possible mechanism to explain differences in dose response $v$. single dose infusion of noradrenaline while estimating thermogenic responses in human subjects. A. V. Kurpad. R. N. Kulkarni. M. Vaz \& P. S. Shezty

The effect of a graded infusion of adrenaline on metabolic rate. forearm electro-myographic activity and oxygen consumption. I. W. Gallen, I. A. Macdonald, K. C. F. Fone \& D. G. Maggs

The effect on the doubly- and triply-labelled water methods of water hydrogen incorporation into body fat in growing pigs. Paul Haggarty, Brian A. McGaw, Malcolm F. Fuller, Susannah L. Christie \& William W. Wong

Evaluation of dual photon absorptiometry for the assessment of body composition. N. J. Fuller. A. Laskey, K. F. Szaz, S. A. Jebb \& M. Elia

The use of $24 \mathrm{~h}$ urine nitrogen to detect bias in the reported habitual food intake of individuals assessed from weighed dietary records. S. Bingham, A. Welch, A. Cassidy, S. Runswick \& C. Gill

Chronic undernutrition in very-low-birth-weight infants who develop bronchopulmonary dysplasia. D. C. Wilson, B. G. McClure, H. L. Halliday, M. McCreid \& J. A. Dodge

Fruit consumption and lung function. B. D. Cox, D. E. Walters, Sharon E. Erzinclioglu \& Margaret J. Whichelow

Food frequency ", weighed intake data in Scottish men. C. Bolron-Smith \& A. C. Milne

Nutrient intakes from current, ex- and never smokers: results from the Scottish Heart Health Study. $C$ Bolton-Smith, M. Woodward, C. A. Brown, W. C. S. Smith \& H. Tunstall-Pedoe

In vivo measurement of changes in body composition: validation against $12 \mathrm{~d}$ continuous whole-body calorimetry. Susan A. Jebb, W. A. Coward, P. R. Murgatroyd, Gail R. Goldberg \& A. M. Prentice

Does consumption of alcohol with a meal promote fat storage? B. J. Sonko, G. R. Goldberg, P. R. Murgatroyd. W. A. Coward \& A. M. Prentice

The effect of previous feeding patterns on the oxidation and tissue $\left({ }^{14} \mathrm{C}\right)$ lipid accumulation after a meal containing $\left(1-{ }^{14} \mathrm{C}\right)$ triolein in the rat. Alison E. Tedstone, Vera llic \& Dermot H. Williamson

The effect of ageing on glutamine metabolism in skeletal muscle of the rat. M. Parry-Billings, B. Leighton. G. D. Dimitriadis, J. Bond \& E. A. Newsholme

Lysine metabolism in young turkeys fed on diets containing different levels of lysine. C. Linda Saunderson \& Paul E. Waibel

The effect of dietary amino acid imbalance on respiration in chick liver. N. S. Jessop, G. Allan. G. Walker \& J. P. F. D'Mello

The influence of glycine and cysteine supplementation on the metabolic response to Escherichia coli endotoxin in rats fed on diets of marginal protein adequacy. R. F. Grimble, R. Hailwood, A. A. Jackson \& C. Persaud

Glycine and cysteine supplementation influences weight gain and liver glutathione. protein and zinc of rats fed on diets of marginally inadequate protein content. R. F. Grimble, A. A. Jackson \& C. Persaud 


\title{
of the Nutrition
}

\section{Society}

\section{VOL. 50 No. 1 MARCH 1991}

\section{CONTENTS}

\section{TASK FORCE REPORT}

University of York

5 HULY Inox

\section{WORKSHOPS}

Fraser-Noble Building. Aberdeen University

2t-28 SEPTEMBER 1989

ASSESSMENT OF ZINC STATUS

Chairman: C, F, Muts, Rowett Research Institute, Aberdeen

The assessment of zinc status: a personal view. Peter J. Aggett

Fraser-Noble Building, Aberdeen University

$20-28$ SEPTEMBER 1480

NUTRITION AND THE SCHOOLCHILD

Chairman: H. Coubrotig. Aberdeen Royal Infirmary

Food, vitamins and IQ. M. Nelson

Nutrient intake in schoolchildren: some practical considerations. G. McNeill, L. Davidson, D. C. Morrison, I $\kappa$ Crombie, J. Keighran \& J. Todman

Nutrition education in Scottish schools. Notes taken by M. E. J. Lean from a presentation by Moira McFarlane

Food choices and preferences of schoolchildren. Jane Thomas

\section{SYMPOSIUM PROCEEDINGS}

\author{
University of Strathclyde \\ $20 / 30$ MARCH 1906 \\ DIET SELECTION \\ Chairman: J. M. Forbes. University of Leeds
}

Diet selection by animals: theory and experimental design. G. C. Emmans

Mechanisms of diet selection: the translation of needs into behaviour. Peter J. Rogers \& John E. Blundell

Diet selection - an ecological perspective. $R$. Moss

Diet selection by grazing animals. John A. Milne

Diet selection of pigs and poultry. $S$. $P$. Rose \& $I$. Kyriazakis

$71-75$

Sensory and experiential factors in the design of foods for domestic dogs and cats. J. W. S. Bradshaw

Development of food choice during infancy. Peter Wright

\section{ABSTRACTS OF COMMUNICATIONS}

\author{
University of York
}

th ULY Y

The effect of the oestrous cycle in rats on fat and protein selection. H. G. Anantharaman-Barr \& J. Décombaz Stable isotope studies of albumin synthesis during normal pregnancy. O.S. Olufemi, T. Lind. P. G. Whittaker \& D. Halliday

[Continued on p. iii of wrapper]

(C) The Nutrition Society, 1991

\section{CAMBRIDGE UNIVERSITY PRESS}

The Pitt Building. Trumpington Street, Cambridge CB2 1RP

40 West 20 th Street. New York. NY 10011-4211. USA

10 Stamford Road, Oakleigh. Melbourne 3166. Australia 